\title{
Black Suns of Melancholy Hart Crane's Treatment of the Sun Motif in the Light of Mircea Eliade's Study of Solar Cults
}

Alicja Piechucka

\section{(c) OpenEdition}

\section{Journals}

Electronic version

URL: https://journals.openedition.org/ejas/9946

DOI: $10.4000 /$ ejas. 9946

ISSN: 1991-9336

Publisher

European Association for American Studies

Electronic reference

Alicja Piechucka, "Black Suns of Melancholy Hart Crane's Treatment of the Sun Motif in the Light of Mircea Eliade's Study of Solar Cults", European journal of American studies [Online], 8-1 | 2013,

document 1, Online since 18 January 2013, connection on 08 July 2021. URL: http:// journals.openedition.org/ejas/9946 ; DOI: https://doi.org/10.4000/ejas.9946

This text was automatically generated on 8 July 2021.

Creative Commons License 


\title{
Black Suns of Melancholy Hart Crane's Treatment of the Sun Motif in the Light of Mircea Eliade's Study of Solar Cults
}

\author{
Alicja Piechucka
}

"Start with the sun, and the rest will slowly, slowly happen."

D. H. Lawrence, Apocalypse

1 On 10 December, 1929, the lifeless bodies of poet and publisher Harry Crosby and Josephine Bigelow, locked "in an affectionate embrace" (Hamalian 73), were found in a room at the New York Hotel des Artistes. The police inquest which followed revealed that Bigelow's death had preceded Crosby's by two hours, and that the two lovers had apparently made a suicide pact. However, the possibility that thirty-one-year-old Crosby was not just a suicide, but also the murderer of his decade younger mistress cannot be excluded (73). The tragic incident was the last chapter in the life of one of the most flamboyant figures on the American expatriate literary scene of the interwar years. Shortly after Crosby's death, his friend Hart Crane wrote a poem entitled "To the cloud Juggler," which was to be published in a memorial issue of transition magazine devoted to Crosby. In this way, Crane paid homage to the man who had supported his talent and promoted his work. Harry Crosby was the first publisher of The Bridge, the force behind the 1930 deluxe edition of Crane's opus magnum. He was also the person who took the poet in and helped him during his stay in Paris.

2 Crosby's short, intense and tragic existence embodied the glamor of the era as well as its darker underside. The traumatic experience of the Lost Generation, the excesses of the Roaring Twenties and the interwar Paris as a hothouse of expatriate literary activity are all part of the rich tapestry of his life. If Crosby had not existed, he would have had to be invented by some novelist of the period. While Crosby's contemporaries "compared him to a character from the pages of F. Scott Fitzgerald" (Fisher 396), he 
could just as well have been the protagonist of a work by Ernest Hemingway, whom he befriended (Hamalian xi). The scion of one of America's wealthiest and most distinguished dynasties, Crosby "volunteered for the American Field Service Ambulance Corps in France" (13) during World War I and "experienced the true savagery of war at Verdun" (14), which won him a Croix de Guerre (14) and left him like so many young men who had matured in the trenches - war-torn. Crosby went on to graduate from Harvard (21) and to scandalize Boston's high society by marrying a woman six years his senior, who had left her first husband, the father of her two children, for him. In Paris, Harry and Caresse Crosby founded the Black Sun Press, which was to publish The Bridge. The couple's passion for all things solar was reflected in the name of the company as well as in that of the mansion they owned, the Moulin du Soleil, situated in the vicinity of the French capital. It was in the Crosbys' "Mill of the Sun" that Crane worked on some sections of his epic poem as well as mixed with the myriads of artists, intellectuals and originals that flowed through the Crosby house (Fisher 397-98).

Dashingly handsome and unabashedly eccentric, Harry Crosby was variously seen "as charming, but odd" (Hamalian 15) or, in the words of Edith Wharton, a "half-crazy cad" (qtd. in Hamalian 31). "Carr[ying] out his antics and excesses without a shred of selfconsciousness" (14), he made a point of dressing all in black or dark blue, wearing an artificial black camellia or gardenia as a buttonhole and painting his nails $(14-15,31)$. The larger than life, Gatsby-esque persona of this "amazing millionaire" (Crane 608) manifested itself in outré ideas, such as, for instance, treating his guests to "Polo with golf sticks on donkeys" (612). A bonviveur, spendthrift, gambler, hard drinker, opium addict and bibliophile $(21,31)$, the decadent, hedonistic Crosby was unconventional in both his tastes and moral standards: he and his wife had an open relationship, and he engaged in numerous love affairs. For all his fantasy and panache, Crosby did, however, reveal a disquieting streak. Consumed with "An obsession with death, dating from his war experiences" (31), he planned to kill himself on the day of the solar eclipse (72).

The choice of death date was far from coincidental, since Crosby, one of whose poems contains the encoded phrase "Harry poet of the sun" (Wolff 204), was a devotee of solar cults. A letter to his mother, written two years prior to his suicide, gives us an insight into how Crosby's sun worship began. "You will be glad to know that it is my swan-song to the decadent and that my next book Chariot of the Sun is to be the other extreme," Crosby declares, before incorporating into his letter what is apparently a quote: "and a sixth sect worshipped an image of the sun formed in the mind. Members of this last sect spent all their time meditating on the Sun, and were in the habit of branding circular representations of his disk on their foreheads, arms, and breasts ..." (qtd in Wolff 193). Following what he himself called his "serious expedition into the Country of the Decadents" (qtd in Wolff 193), Crosby transferred his fascination to another object. "So," in the words of his biographer, "the sun was elected. He would stare into its explosive eye and resolve by its creative energy his illuminations, loop-the-loops of fancy, crazy quirks. The sun would contain everything" (Wolff 193). However, as Wolff proceeds to inform us, the exact nature of the solar cult to which Crosby devoted himself is hard to pinpoint:

it is not easy to describe with any precision what it was to which Harry was converted. As an object of worship the sun is various and slippery, and in his rush toward a coherent system of belief and symbolic representation Harry confused unity with totality, so that he attempted to absorb within his belief every aspect 
and atom of the sun that man in his wisdom or silliness had ever found cause to venerate. The sun - all-seeing eye, blinding light, source of life, killer of Icarus and Phaëton, masculine principle, creative principle, godhead and the eye of the godhead - is at once comprehensive and a paradigm of ambiguity. (194) became a mishmash of ideas and beliefs, "a hotchpotch of Christian faith in an afterlife and pagan rituals" and of "every scrap he could find left over from the Aztecs or Pharaohs, the Greeks or Romans, Goethe or D. H. Lawrence, Rimbaud or the tarot pack" (195).

Crosby combined his worship of the sun - itself, as we have seen, composite - with his literary pursuits, as the titles of two of his poetry collections, Chariot of the Sun and Shadows of the Sun, demonstrate. To prove that Crosby's "sun-stroke was extreme" (Wolff 195), his biographer quotes selected poem titles from Chariot of the Sun, which "give a sense of Harry's obsession." The list encompasses "Quatrains to the Sun," "Cinquains to the Sun," "Sun Rhapsody," "Angels of the Sun," "Sundrench and Sons," "Photoheliograph," "Sun-ghost," "Suns in Distress," "Young Sun," "Sunset, Sunrise," "Epitaph for the Sun," "Sun Testament" as well as "Proposed Titles for Sun-poems," all of them works whose thematic content fulfills the "solar" promise inherent in their titles (196). Crosby's devotion to the sun did not, however, enhance the quality of his poetic output, referred to as "execrable" by one contemporary commentator (Strassner), an opinion which differs in phrasing rather than in essence from those expressed by D. H. Lawrence (qtd in Wolff 196, 203-204), Ezra Pound (qtd in Wolff 304) or Crosby's biographer (Wolff 187, 196, 197). While Crosby's literary merit is questionable, the genuineness of his convictions and his devotion to art and sun worship is not (196). As Wolff argues, the sincerity and strength of the beliefs which fueled his pursuits may in fact be responsible for the tragic brevity of Crosby's life: "Harry's dogma was high, but his control was loose. Like Icarus, of whom he wrote, he flew toward the sun till it melted his wings of wax, and plunged him down" (194). Crosby was, in short, "driven to madness by yoked nemeses, by perfect freedom - given or grabbed - and by his fanatical fixation on the naïve principles of a vision of death in the sun" (205).

7 In a letter to Malcolm Cowley, Hart Crane remarked that "It takes a book to describe the Crosbys" (608). However, when he was faced with the sad task of writing an elegy for Harry, he had to confine himself to five quatrains. Despite his fondness for his late patron and friend, Crane was dissatisfied with the result, believing his poem to be "uninspired" and suggesting that Crosby's widow should perhaps refrain from publishing it (Fisher 424). Though some critics seem to subscribe to the author's opinion of "To the Cloud Juggler," claiming it is "Far from being one of Crane's best poems" (Khan 54), the aim of the present article is to show that the elegy for Crosby should not be dismissed as unworthy of critical attention. In order to prove my point, I have decided to superimpose Mircea Eliade's study of solar cults on Crane's poem, to which, for reasons discussed in the previous paragraphs, the sun motif is central. In fact, it may be the case that "To the Cloud Juggler," a "solar" poem, shares the fate of solar symbolism, whose perception changed as mankind evolved from the "primitive" to the "modern" (Eliade 125):

(...) unlike other nature hierophanies, such as the moon or water, the sacred meaning expressed in the sun is not always clear to the modern Western mind. Or, more precisely, what is clear, and therefore easily grasped, in any sun hierophany is 
most often only what remains after a long process of rationalization has worn it away and it is brought to us, without our realizing it, by way of language, custom and culture. The sun has now become simply one of the commonplaces of what is in a vague sense religious experience, solar symbolism being reduced to little more than a series of gestures and phrases of no very vital significance. (125)

One of the aims of Eliade's study is perhaps to counteract the banalization of all things solar "in the experience of modern man" (125). Similarly, it is the aim of the present article to prove that in "To the Cloud Juggler" Crane is not merely a poetic landscapist who contents himself with producing a verbal depiction of a sunlit seascape, embellished with vague or self-explanatory evocations of the elements and natural phenomena.

Eliade's discussion of sun worship and the role it plays in various cultures is helpful in elucidating Crane's poetic text, bringing out its hidden meanings and uncovering its potential. Eliade's insights into solar hierophanies - hierophany being a term promulgated by Eliade himself and denoting the way the sacred manifests itself in the world - inspire the literary exegete to read meanings which transcend the most obvious associations into the poem. The work by Eliade, arguably the world's leading historian of religions, that I refer to is his seminal 1949 study Patterns in Comparative Religion. Having died in 1932, Crane could not have been familiar with the work of the Romanian-born scholar. Nevertheless, the fact remains that the poet of The Bridge did show a keen interest in myth, rituals, folklore and anthropology, from which Eliade's interdisciplinary study cannot be dissociated. One of the symptoms of what Tapper refers to as "Crane's attraction to ethnography" (108) was his reading, six years prior to Crosby's death, of The Golden Bough (Fisher 200), one of the seven books by James George Frazer included in the bibliography of Patterns in Comparative Religion. That "the approach to the study of religion fostered by Eliade's insights has been utilized by scholars in a variety of other disciplines besides the history of religions, including anthropology, philosophy, history, art history, and literature" (Holt xii) remains unarguable. In fact, Eliade himself draws on examples derived from world literature to reinforce the points he makes. In the present article, it is my intention to take the opposite direction, applying Eliade's findings to literary exegesis.

10 A source of light and energy, the sun is universally regarded as the most important symbol of life (Chenel and Simarro 231). The fact that it had such a fascination for the death-obsessed Crosby, who once declared that "For the poet there is love and there is death and infinity" (qtd. in Fisher 419), may thus be somewhat surprising. For the same reasons, it may also seem out of place in an elegy. Mutually incompatible as they seem, the sun and death are in fact inextricably linked, and, Crosby's idolatrous love of the sun left aside, Crane had good grounds for interlinking them in "To the Cloud Juggler." The motif of the black sun, which figures in the title of the present article, alludes, on the one hand, to the name of the publishing house founded by the Crosbys and, on the other, to "El Desdichado," a poem by Gérard de Nerval, a precursor of French symbolism, of which Crosby was an ardent admirer (Hamalian 29). The speaker of Nerval's sonnet, who confesses to having "crossed Acheron" (Murphy 31) victoriously on two occasions, presents himself as a widower, associating the black sun with death, mourning and melancholy:

I am the man of darkness - the bereft - the inconsolate

The Prince of Aquataine with the abolished tower:

My only star is dead and my lyre 
Bears the Black Sun of melancholy. (31)

Such an association has a long tradition and is rooted in myth and folklore. In preColumbian America, and, later, in Western art, the black sun symbolized death, misery, sadness and melancholy (Chenel and Simarro 231). As Eliade observes, "the sun may still assume an important function in the sphere of burial beliefs, in all that concerns man's state after death" (135) and its "connection with the other world, with the spheres of darkness and death, is clear in the most primitive solar hierophanies and is rarely lost to view" (142). Present in culture, the sun-death connection has also made its way into literary genetics, the above-mentioned poem by Nerval being by no means an isolated case. In his study of the modern elegy, Jahan Ramazani points out that solar imagery is an important component of the genre $(3,4,45,139)$, as is the motif of light $(74,218,296)$. As for Crosby's own poetry, with the twin obsessions which inform it, death and the sun, his poem "Photoheliograph" is a case in point:

black black black black black
black black black black black
black black black black black
black black black black black
black black SUN black black
black black black black black
black black black black black
black black black black black
black black black black black
black black black black black (qtd in Wolff 197-8)

The paradox of the life-sun-death connection in the poem quoted above is also what strikes Crosby's biographer, who writes:

This black sun was no invention of Harry's, but the alchemist's Sol niger, prime matter, the unconscious in its unworked, base state. The black sun is at its nadir, hidden, and all is night. In the Rig-Veda the sun during its night crossing is at its most magical and portentous. It must and shall be resurrected, as Harry knew he should persist again, in and like the sun, beyond his own sun-fall. Here again, paradox and ambiguity: the sun that gave sea, soil, and life also stared down without pity at its creations and withered them, dried them out, burnt them. Or failed to shine, winking while life failed. Where the sun is, there also find the death principle, the chaos that reigned before light dispelled it, the chaos that Harry's life and work replicated in miniature. (Wolff 198)

Solar imagery recurs in Crane's poetry, his magnum opus The Bridge being particularly relevant. In his last poem, "The Broken Tower," Crane evokes "that tribunal monarch of the air / Whose thigh embronzes earth" (106), whom Brunner identifies as "a God or the sun or some elemental force of undeniable power" (241). The critic speaks of "The image of a sun-god as a giant," opposed to mere mortals (241). The notion of the sun's unchallenged supremacy similarly informs Crane's elegy for Crosby. Though the somewhat cryptic title does not contain any explicit solar references, it is not unfeasible to read it as a periphrasis for the word sun: the sun-god, the ruler of the universe, is vested with the power to gather or disperse the clouds. From the very beginning, "To the Cloud Juggler" takes the form of an invocation to the sun, addressed directly in the apostrophe inserted into the poem's second stanza:

What you may cluster 'round the knees of space

We hold in vision only, asking trace

of districts where cliffs, sea and palm advance

The falling wonder of a rainbow's trance. 
Your light lifts whiteness into virgin azure...

Disclose your lips, o Sun, nor long demure

With snore of thunder, crowding us to bleed

The green preëmption of the deep seaweed. (Crane 79, italics mine)

Deified by the late Crosby, the sun analogically assumes a divine quality in Crane's poem. In classic invocations, the poet pleads for inspiration. The speaker of "The Cloud Juggler" also makes a series of pleas, which, on the grammatical level, translate themselves into a consistent use of the imperative in stanza two, which is quoted above, as well as in the three remaining stanzas of the poem:

You, the rum-giver to that slide-by-night,-

The moon's best lover, - guide us by a sleight

Of quarts to faithfuls - surely smuggled home -

As you raise temples fresh from basking foam.

Expose vaunted validities that yawn

Past pleasantries ... Assert the ripened dawn

As you have yielded balcony and room

Or tempests - in a silver, floating plume.

Wrap us and lift us; drop us then, returned

Like water, undestroyed, - like mist, unburned ...

But do not claim a friend like him again,

Whose arrow must have pierced you beyond pain. (Crane 79)

The poem's closing couplet focuses specifically on the man whose memory the elegy celebrates: as Sy Khan explains, "The "arrow" of the last line is a direct reference to Crosby, who, as his friends knew, had for some years signed his letters with a little diagram depicting an arrow in flight toward the sun, an emblem of the soul in its final flight" (54-55). The biographical explanation left aside, the arrow has broader implications. Bringing to mind the circumstances of Saint Sebastian's martyrdom, it sends the reader back to, on the one hand, the substantial homoerotic dimension of Crane's poetry, pointed out in Thomas Yingling seminal monograph, and, on the other, the inextricable connection between art and suffering. However, given Crosby's heterosexuality, Saint Sebastian's unquestionable status as a gay icon may be less relevant than his status as the archetypal artist figure, famously observed by Thomas Mann. Gustav von Aschenbach, the homosexual protagonist of Death in Venice,comes to see Sebastian as an embodiment of not merely gay suffering, but rather suffering in the name of art, of all the sacrifices which true artists must make and whose consequences they must patiently bear. Returning to the biographical details of Crosby's life, the inescapable analogy seems to be that between his suicide and the sacrifice impersonated by Saint Sebastian. Shortly after the tragic events at the Hotel des Artistes, Crane wrote of Crosby's death, "it is quite probable that he desired it as one more "experiment"' (637), elsewhere referring to it as "imaginative, the act of a poet" (qtd in Wolff 294). In a similar vein, Crosby's biographer argues that the author of Chariot of the Sun "anticipated - indeed, insisted - that his act be read as a literary work" (Wolff 295), and quotes John Wheelwright's verse about Crosby, with its conclusion that "His death was his best poem" (qtd in Wolff 302).

If Crosby is - unsurprisingly - present in "To the Cloud Juggler," so is Crane himself. In classic epic poems, one of the many roles of the invocation consist in revealing the narrator's presence to the reader (Kulawik 338). In "To the Cloud Juggler," Crane is represented by the aquatic motifs "which he associates with himself" (Khan 54), confirming a remark famously made by Crosby, who noted his and Crane's common 
attraction to the elements: "he is of the Sea as I am of the Sun" (qtd. in Fisher 398). Moreover, Crane's presence is also inherent in the first person plural personal pronoun used both in its subject and object forms. It takes a careful analysis of the poet's use of solar imagery and symbolism to attempt to find out what the elegy says not just about Crosby and Crane, but also about life and art.

"The Circumstance," an unfinished poem Crane worked on in 1931 during his stay in Mexico, one of the centres of ancient solar cults (Eliade 124), is "addressed to Xochipilli, sun god of the Aztecs and patron of youth, joy, poetry and masculine fecundity" (Fisher 466). Discussing Crane's exploration of Mexico's past and present, his biographer points out an affinity between the poet of The Bridge and another leading modernist author:

It was this aspect of Mexico as a vast cultural palimpsest that had fascinated D. $\mathrm{H}$.

Lawrence, whose novel The Plumed Serpent, published only five years before Hart's arrival, had galvanized the Anglo-American literary world and made the country, long synonymous with danger and unrest, a fashionable destination. (447)

The Plumed Serpent thus had a marked impact on the literati of the day. A case in point is Harry Crosby: "he was profoundly influenced" by this "symbol-ridden romance, set in Mexico, rife with pagan gods and ancient rituals of blood sacrifice" (Wolff 199) and resembled the novel's female protagonist in that he "felt himself pulled toward the source, toward life-impulses centered in the sun" (199). Crosby himself acknowledged the influence of Lawrence, the author of the introduction to his Chariot of the Sun (203) and of a story entitled Sun, published by the Black Sun Press (202): "The Plumed Serpent is the most inspiring novel I have read since The Enormous Room" (qtd in Wolff 200). As Wolff observes,

Lawrence's worship of the sun was more coherent and better focused than Harry's. For him the sun was the primal source, the locus of energy and creation. The sun could renew and transform. From his direct experiences in Mexico, and among the Indians of New Mexico, together with his use of the cerebrations of Sir James Frazer, Jung and Nietzsche, he had fashioned a doctrine of oppositions in which primal vitality and civilized self-denial were in perpetual conflict. (203)

In a somewhat similar vein, the speaker of Crane's "The Circumstance," a "lyric bid to outpace Time" (466), speculates on what could happen
(...) If you
Could drink the sun as did and does
Xochipilli, - as they who've
Gone have done, as they
Who've done. (143)

Crane's answer to his own poetic query is:

You could stop time, give florescent

Time a longer answer back (shave lightning,

Possess in halo full the winds of time)

A longer answer force, more enduring answer

As they did - and have done.... (143)

21 It is thus clear that the poet associates the sun - and, by extension, those who are close to it either for having been anointed by it or for worshipping it - with absolute power, which makes it possible to counteract the passage of time and transcend the confines of ordinary human existence. The speaker's yearning for such supreme power seems to underlie not just "The Circumstance," but also the poem under discussion in the present article. The opening stanza of "To the Cloud Juggler" is structured in a way 
which clearly opposes the vastness of the universe which the sun "may cluster" to what "We hold in vision only," thereby opposing the superior solar "you" to the infinitely humbler "us."

The very fact that Crane turns to the sun in the poem, in addition to being motivated by the biographical details of Crosby's life, encourages the reader to ponder on the exact identity of the "we." The first question which remains to be resolved is whether the speaker - who, given the circumstances of the poem's composition, may be safely assumed to be identifiable with Crane - means anyone but himself when he uses the first person plural personal pronoun. It may of course be argued that we have to do with the use of either pluralis maiestatis, justified by the solemnity of the occasion, or pluralis modestiae. The latter would, however, mean that the speaker expresses his own ideas, at the same time trying to make them seem impersonal and common to all people (Sławiński 360). It is also possible that the speaker addresses the sun on behalf of a group of people. This group, however, does not necessarily have to comprise all mankind: it may be limited to individuals who share certain characteristics, though by no means does it have to be limited to those who knew and befriended the man to whom Crane pays homage in his elegy. When, in the first stanza, the sun's supreme embrace of the universe is set against the "cliffs, sea and palm" which those inferior to the sun "hold in vision only," the double meaning of the word vision has to be taken into account. While it may denote simply the ability to see, it may also stand for the mental picture or idea existing in the mind of a visionary. The stanza may thus be read, literally and somewhat simplistically, as one which presents the sun's taking possession of the wonders of nature, which mere mortals can only see, in a way which is always imperfect and fragmentary. However, it may also be interpreted as evocative of the fate of those whose vision transcends that of ordinary people, though their power cannot rival that of the sun, which is their source of inspiration. In other words, the sunworshippers whom Crane evokes - and in whose name he speaks in the poem - are visionaries: artists, idealists and free spirits, like Crosby and himself. If we assume that the poem's title does not - as I have proposed earlier in this article - denote the sun, but also Crosby himself, the community of visionaries is that of "cloud jugglers," the word cloud connoting - as even metaphors from everyday speech demonstrate daydreaming and detachment from reality, and the verb juggle suggesting supreme skill, but also risk. If we now look at Eliade's study, we find a passage which turns out to be helpful. Noting "that, on the other side of the Atlantic, the solar religion was developed only in Peru and Mexico, only, that is, among the two "civilized" peoples of America, the only two who have attained any level of real political organization" (124), Eliade concludes that there exists "a certain connection between the predominance of sun religions and what I may call "historic" destinies" (124). He further elaborates on the link between solar supremacy, power and progress:

It could be said that where "history is on the march", thanks to kings, heroes, or empires, the sun is supreme. A great many other hypotheses, some frankly whimsical, have been put forward to explain this parallelism between sun worship and the spread of civilization in history. Some authors have even spoken of "Children of the Sun" spreading both the cult of the sun and the basic principles of civilization, during the course of endless migrations. (124)

Would it be far-fetched to claim that in Crane's poem artists or, more precisely, poets are seen as solar heirs, akin to monarchs and historic heroes? What the two groups have in common is, after all, their capacity for vision, if not all-embracing like that of 
the sun, then at least original and innovative enough to forward progress. It must be remembered that, as I have demonstrated at length in another article, in "Ave Maria," part one of The Bridge, Crane presents Columbus, the ultimate visionary, not just as a historical figure of the utmost importance, but also as a verbalist, and therefore, in a sense, a poet (Piechucka 99-114), suggesting the existence of some spiritual kinship between great artists and great leaders.

The points made in the preceding paragraph become even more plausible when we consider the powers the sun is traditionally endowed with. In this context, Eliade speaks of "the dynamism, intensity and drama of the new atmospheric, fertilizing, vegetation figures" (127) and of the "all-embracing importance of vital values and of "Life"" (127). The Romanian scholar also cites the example of "the supreme gods of Mesopotamia," who "often combined the prerogatives of fertility with those of the sun" (127), and concludes that "This conjunction of sun and vegetation elements is clearly to be explained by the Sovereign's having the added role of storing and dispensing "Life", both on the cosmic and on the social level" (127). In addition to being motivated by biographical factors and the funeral dimension of the solar, which I have already hinted at and to which I shall return, the fact that Crane addresses the sun in a poem about death serves perhaps to emphasize not just the closeness of the two, but also the fact that "To the Cloud Juggler" is an artist's tribute to an artist. The sun is the addressee of the poem not only because Crane's late friend worshipped it, but also - or perhaps primarily - because the artist's creativity mirrors the sun's life-giving power. Drawing on cults in Indonesia and America, Eliade notes that "the sun god" is often entrusted with "creating the universe" and "advances to the position of demiurge" (130). Being the "servant" or "son" of "the Supreme God of the sky," the solar divinity is expected to "continue and complete the work of creation begun by him" (130): his creativity is not unlimited because "he is subordinate to the creator, and holds the latter's mandate to complete the work of creation" (130). The speaker of "To the Cloud Juggler" finds himself in a somewhat analogical position: he too is subordinate to the sun and empowered by it. As such, he speaks in the name of those who attempt to capture but traces of "The falling wonder of a rainbow's trance." The oxymoronic combination of falling, which may suggest the rainbow's shape, but also denote decline, and wonder, simultaneously evokes the beauty, magnitude and difficulty of the artist's task. Interestingly, the rainbow is mentioned in Eliade's study as a phenomenon "associated with the sun" or "the "sun's brother" (128). The homophonic nature of the words sun and son makes it tempting to apply the same pattern of family relations to Crane's poem and see both the poet and the man he pays tribute to as sons of the sun or perhaps siblings of the sun.

The structure of the poem's second stanza may be described as prayerful. The speaker both lauds the sun's power to elevate and edify ("Your light lifts whiteness into virgin azure...") and adopts a beseeching tone, apparently afraid that the solar divinity might not bestow on its worshippers the grace they implore ("Disclose your lips, o Sun, nor long demure / With snore of thunder (...)"). Dismayed at the prospect of being made "to bleed / The green preëmption of the deep seaweed," the speaker may wish to evoke, in what Berthoff calls "a line of fine Shakespearean pastiche" (53), a fear of the sun's anger or displeasure, which might - metaphorically - doom its worshippers to reside at the bottom of the sea, suggestive perhaps, as it is in another poem by Crane, "At Melville's Tomb," of abandonment and oblivion. At this point, a reader of Eliade's study 
is reminded of the scholar's description of prayers offered to the sun god by certain Indonesian peoples, as well as of the orgies held in worship of the sun (133-34). The words of the prayers quoted by Eliade reveal the details of a feast which constitutes the culmination of a fertility rite and to which the local sun worshippers invite their idol: the solar divinity is offered food and drink, but is also expected to provide "food supplies" (133) and guarantee fecundity, "rain, the fertility of the fields and the wealth of the community" (133). If, as has been suggested in the previous paragraph, artistic creativity may be seen as a reflection of the solar god's demiurgic power, it does not seem far-fetched to draw a parallel between the sun worshippers praying for fecundity and an artist's need for inspiration. Of the "two basic theories about inspiration," which identify its source respectively as lying either "outside the writer" or "within him," the "external-force theory," which points out the "divine origin" of inspiration, prevalent since antiquity, was superseded by the late-eighteenth-century belief in "individual genius" (Cuddon 451). Though "Few people now, except those with 'romantic' ideas about it, believe in inspiration" (451), it must be remembered that Crane is in many respects an heir of literary romanticism. The romantics, however, favored the notion of internal inspiration (Sławiński 306) while Crane's use of invocation in the poem seems to imply the presence of a muse or divinity, as it did in ancient literature. Crane's elegy for Crosby may thus be read, on the one hand, as a poem reasserting the romantic value of inspiration as such, regardless of its source, and, on the other hand, the modernist poet's tribute to the ancient origins of his art. In addition to bringing to mind the notions of furor poeticus or furor divinus discussed in the preceding paragraph, Eliade's insights into the celebrations inherent in fertility rites also shed new light on the central stanza of Crane's poem. In what constitutes an interesting, but also, I would argue, partly mistaken reading of this particular stanza, Paul Giles focuses on the epithets "the rum-giver to that slide-by-night" and "The moon's best lover." In Giles's interpretation, both refer to Crosby. Reminding the reader that " 'moon' or 'moonshine' was Twenties slang for bootleg whisky" and that the stanza also contains "imagery of concealment," the critic points out that the passage draws on dual deception. To "the great importance of deception when trading in liquor during the Prohibition era" is added "the deception of the poem, the way bathetic alcoholic puns are secretly undermining the poem's idealistic pretensions" (Giles 160). This leads to the conclusion that Crane skillfully combines the low and the lofty in the poem:

Calling Crosby "The moon's best lover" seems to be a pleasant tribute to his Romanticism until we know that moon puns on whisky. The pun does not cancel the spiritual aura associated with Crosby, but it reveals that for him clouds were indeed "juggled," that an element of trickery and alcoholic illusion was a necessary preliminary to Crosby's transcendent vision. (...) Crosby loves the Romantic moon and moonshine whisky both at once; and the pun, swinging between opposites, allows this constant interpenetration between ideal and real. (160-61)

While such a reading is refreshing and not entirely unconvincing, it is hard to accept without reservation. It is true that Crosby was an inveterate reveler, known for giving and attending wild parties, and that he found an eager fellow reveler in Crane. It is true that Crosby's - and, for that matter, Crane's - "imaginative feats were helped along by alcohol" (160). It is also true that Crane formed a relationship with the Crosbys during Prohibition, though, with the exception of the few days prior to Crosby's death in New 
York, the social gatherings in which the two poets participated took place in France, where the sale of alcohol was legal. The problem with Giles's interpretation is that it seems to ignore the entirety of the poem, in which the speaker consistently addresses the sun, stanza three being no exception. The apostrophe "rum-giver" is, as we must remember, preceded by the personal pronoun "You," which opens the stanza, and there is no reason to believe that the antecedent of this pronoun is Crosby rather than the sun. Giles's comments are, however, useful insofar as they emphasize the motif of feasting, which in turn sends us back to Eliade's study. Since all the indications are that the sun remains the addressee throughout the poem, it is possible to see in the wild parties evoked in stanza three a variation on the orgies held by sun-worshippers, a modern-day fertility rite. The sun would be "the rum-giver" in the sense that it constitutes a source of energy, intoxication and elevation, which sustained Crosby the way poetry and alcohol did. On a more literal level, the sun plays the role of "rumgiver" because it fuels plant life, necessary for creating alcohol.

The other phrase on which Giles's reading rests, "The moon's best lover," encourages the poem's exegete to examine the relationship between the sun and the moon. Eliade's study of the sun and solar cults abounds in references to the lunar. In various cultures, the moon and the sun are bound by family ties, being either siblings, that is the two sons (Eliade 128) or, respectively, the daughter and son of the Supreme Being (129), spouses (130) or, respectively, father and son (142). In addition, the sun and the moon are subject to gender differentiation, though the sex attributed to each of them varies according to the set of beliefs held by a particular community $(129,134)$. The idea of the sun and the moon's sexual union is also encountered: for instance, it is to such a union that the Indian Korkus trace their ancestry (135). "The Samoyeds see the sun and moon as the eyes of Num (that is, the sky): the sun is the good eye, the moon the evil eye" (128), while "The Yuraks of the forests consider the sun, the moon, and "the thunderbolt bird" as symbols of Num" (128). Eliade also cites the example of one tribe, the Birhors, who make offerings to the sun "on the day of the full moon" (131) because the sun god "is not looked on as infallibly efficacious, for the faithful are prudent enough to draw as well upon the forces of moon, earth and fields which have control over all fecundity" (131). The examples given by Eliade show that in different cultures the moon and the sun constitute binary opposites and that the lunar is believed to complete the solar. Such polarity may also be seen as a prerequisite for harmony, as the notion of sun-moon unity found in Buddhism proves:

(...) within the framework of Buddhism, as indeed that of all Indian mystical religions, the sun does not always have the supreme position. India's mystical physiology, particularly Yoga and Tantra, attributes to the sun a definite "physiological" and cosmic sphere as against that of the moon. And the aim common to all these Indian mystical techniques is not to achieve supremacy over one of these spheres, but to unify them, to effect, in other words, the reintegration of the two opposing principles. It is just one of the many variants on the myth and metaphysic of reintegration; in this case the balance of opposites is expressed in the cosmological formula sun - moon. (146-47)

It is possible to read a similar yearning for plenitude into Crane's poem. If the speaker of "To the Cloud Juggler" turns to the sun for inspiration, he also incorporates the lunar dimension into what is in fact a poetic plea for a completeness of artistic vision, mirroring that of the sun-moon relationship. This quest for wholeness and perfection, which may underlie creative endeavors, seems to find further expression in stanza 
four, when the speaker implores the solar deity to "Expose vaunted validities that yawn / Past pleasantries" and to "Assert the ripened dawn."

31 The "alcoholic" metaphors of the poem's central stanza should not obscure the fact that Crane associates the sun with the notion of guidance, as lines two and three explicitly demonstrate. The concept of the sun as a guide is reinforced in the closing stanza, where the speaker - together with the group of people who make up the "we" of the poem - abandons himself to the solar power, expecting it to take care of and lead him - or, more precisely, "them" - in an almost physical sense. In what is another plea addressed to the sun, the speaker evokes a series of prospective upward and downward movements: "Wrap us and lift us; drop us then, returned / Like water, undestroyed, like mist, unburned ....". Before we dismiss the couplet as a graceful but somewhat banal evocation of a solar ballet, it seems worthwhile to return to Patterns in Comparative Religion again. One of the subchapters of the section devoted to solar cults is entitled "The Sun as Hierophant and Psychopomp," the cryptic title identifying the sun as the leader of the dead. Therein Eliade discusses the notions of solar identification and solar initiation as well as the interrelation between the solar and the funeral in the context of death and rebirth. "In the Wiradjuri and Kamilaroi tribes," the Romanian scholar notes, the initiated "becomes so anew as a result of his ritual death from which he rises identified with the sun" (Eliade 135). Similarly, "the souls of the dead" may be said to be "already initiated," since "they have already undergone death and resurrection, and have each become a "sun"" (135). Such religious beliefs put a subtler and more complex perspective on the seemingly mundane and trivial phenomenon that is sunrise: "The sun in this way becomes the prototype of the "dead man rising again every morning" (135-36)," "a god (hero) who does not die (as does the moon), but who passes through the empire of death every night and returns the next day eternal and unchanging" (136).

We have already seen that Crane conjures up images of the rising sun in the poem, as he shows the solar power "rais[ing] temples fresh from basking foam," which in all probability suggests sunrise on the shore, and "Assert[ing] the ripened dawn." It may thus be argued that in imitation of the sun, the speaker and his like-minded peers wish to rise at dawn and set at dusk. However, not being potent enough to do so unaided, they need to be "wrapped," and subsequently "lifted" and "dropped" by the sun. Significantly, the fall which the verb drop may suggest is not something threatening or irreparable, since the speaker and his peers are to be "returned" unharmed and untouched, or, to use Crane's own words, "undestroyed" and "unburned," each sunset or death - inevitably entailing another sunrise, symbolic of rebirth. While it is possible to simply associate the fact that they survive their solar flight intact with Crane's - and, by extension, his peers' - identification with water in all its forms, be it the sea or mist, a more insightful reading of the poem enables us to interpret the motif in the light of the concept of solar immortality. Such immortality was an attribute of Egyptian pharaohs (Eliade 140). However, if we work, as I already have earlier in this analysis, on the assumption that artists fall into the same category as political leaders, that they possess some god-like, demiurgic powers, the solar immortality implied by the motif of sunrise, and the "human sunrise" wished for by the speaker, is tantamount to artistic immortality. As Eliade points out, the Mesopotamian god Shamash has the power to revive the dead and is at the same time "the patron of prophets and soothsayers, a function that is always connected with the world of the dead and the domains of earth 
and burial" (142). The gift of immortality - or the power to immortalize - may thus go hand in hand with the prophetic gift, and both are the artist's domain. In other words, the conclusion of Crane's poem voices the time-honored hope shared by most artists: that their cuvre will prove immune to the passage of time, or at least more durable than they themselves are. Artistic fame is a form of immortality, which is perhaps what Harry Crosby had in mind when he wrote, in a letter to Crane quoted by Fisher, apropos of the manuscript of one his poems: "I am so damn glad to have this poem in MSS someday when we are all dead they will be screaming and cutting each other's throats for the privilege of having it. It is sure as Kubla Khan is sure as Blake is sure as Ozymandias and Anabase are sure" (400).

\section{BIBLIOGRAPHY}

Berthoff, Warner. Hart Crane: A Re-Introduction. Minneapolis: University of Minesota Press, 1989.

Brunner, Edward J. Splendid Failure. Hart Crane and the Making of "The Bridge." Urbana and Chicago: University of Illinois Press, 1985.

Chenel, Álvaro Pascual and Alfonso Serrano Simarro. Słownik symboli. Warszawa: Świat KsiĄżki, 2008.

Crane, Hart. Complete Poems and Selected Letters. New York: The Library of America, 2006.

Cuddon, J. A. Dictionary of Literary Terms and Literary Theory. London: Penguin Books, 1991.

Eliade, Mircea. Patterns in Comparative Religion. N.p.: University of Nebraska Press, 1996.

Fisher, Clive. Hart Crane: A Life. New Haven and London: Yale University Press, 2002.

Giles, Paul. Hart Crane: The Contexts of "The Bridge." Cambridge: Cambridge University Press, 1986.

Hamalian, Linda. The Cramoisy Queen: A Life of Caresse Crosby. Illinois: Southern Illinois University Press, 2009.

Holt, John Clifford. "Introduction.” Mircea Eliade. Patterns in Comparative Religion. N.p.: University of Nebraska Press, 1996. xi-xvi.

Khan, Sy."Hart Crane and Harry Crosby: A Transit of Poets." Journal of Modern Literature. Vol.1, No. 1 (1970), 45-56.

Kulawik, Adam. Poetyka. Wsț̨p do teorii dzieła literackiego. Kraków: Antykwa, 1994.

Murphy, Paul. The New Life. Belfast: Lapwing Publications, 1992.

Piechucka, Alicja. "Dream Cancels Delirium, Delirium Cancels Dream: Extremes of Experience in Hart Crane's ‘Ave Maria' and Arthur Rimbaud's ‘Délires.” The Dream. Eds. Ilona Dobosiewicz and Jacek Gutorow: Opole: Uniwersytet Opolski, 2011. 99-114.

Ramazani, Jahan. Poetry of Mourning. The Modern Elegy from Hardy to Heaney. Chicago: University of Chicago Press, 1994. 
Sławiński, Janusz Ed. Słownik terminów literackich. Wrocław: Zakład Narodowy im. Ossolińskich, 1989.

Strassner, Anne. „Epitaph For the Sun.” Web The Harvard Crimson. Sep.30, 1976 http:// www.thecrimson.com/.

Tapper, Gordon. The Machine that Sings: Modernism, Hart Crane, and the Culture of the Body. New York and London: Routledge, 2006.

Wolff, Geoffrey. Black Sun: The Brief Transit and Violent Eclipse of Harry Crosby. New York: New York Review Books, 2003.

\section{ABSTRACTS}

The aim of the article is to examine Hart Crane's use of solar imagery in the light of Mircea Eliade's study of solar cults. The Crane poem under consideration is his elegy for Harry Crosby, a publisher, fellow poet and friend, who was a sun devotee and one of the most flamboyant figures on the 1920s American literary scene. The work by Eliade on which the article draws is his seminal book Patterns in Comparative Religion. Filtered through the insights provided by the Romanian-born scholar, Crane's elegy, all too often dismissed as a minor poem, takes on new meanings. In the light of Eliade's illuminating analysis of solar symbolism and the role the sun plays in different cultures, the poem emerges as a carefully constructed reflection on the artist's fate. The article demonstrates that Crane's use of seemingly familiar solar imagery may in fact serve to highlight the need for inspiration, the pursuit of perfection and completeness or the yearning for artistic immortality - issues inscribed into a neo romantic view of the artist's condition.

\section{INDEX}

Keywords: Columbus, Edith Wharton, Edward J. Brunner, Ernest Hemingway, F.Scott Fitzgerald, Gérard de Nerval, Gordon Tapper, Harry Crosby, Hart Crane, Jahan Ramazani, James George Frazer, Josephine Bigelow, Malcolm Cowley, Mircea Eliade, Paul Giles, Sy Khan

\section{AUTHOR}

\section{ALICJA PIECHUCKA}

Instytut Anglistyki Uniwersytet ŁódzkiŁódź Kościuszki 65Poland 